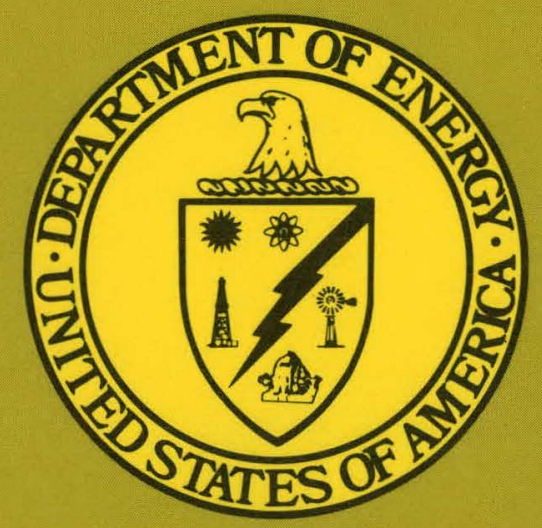

DOE/PETC/TR-80/7

Distribution Category UC-90d

METHANATION IN CATALYST-SPRAYED TUBE WALL REACTORS: A REVIEW
by H.W. Pennline
R.R. Scheh1
W.P. Haynes
A.J. Forney

Date Published - September 1980

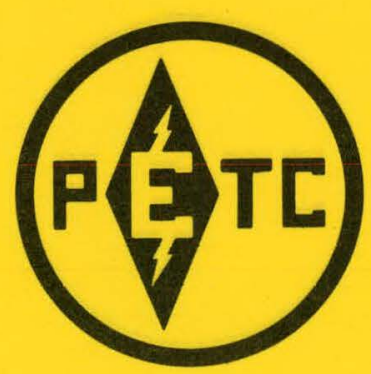

PETC $80-B(1-80)$

Pittsburgh Energy Technology Center

Pittsburgh, Pennsylvania 


\section{DISCLAIMER}

This report was prepared as an account of work sponsored by an agency of the United States Government. Neither the United States Government nor any agency Thereof, nor any of their employees, makes any warranty, express or implied, or assumes any legal liability or responsibility for the accuracy, completeness, or usefulness of any information, apparatus, product, or process disclosed, or represents that its use would not infringe privately owned rights. Reference herein to any specific commercial product, process, or service by trade name, trademark, manufacturer, or otherwise does not necessarily constitute or imply its endorsement, recommendation, or favoring by the United States Government or any agency thereof. The views and opinions of authors expressed herein do not necessarily state or reflect those of the United States Government or any agency thereof. 


\section{DISCLAIMER}

Portions of this document may be illegible in electronic image products. Images are produced from the best available original document. 


\section{DISCLAIMER}

"This book was prepared as an account of work sponsored by an agency of the United States Government. Neither the United States Government nor any agency thereof, nor any of their employees, makes any warranty, express or implied, or assumes any legal liability or responsibility for the accuracy, completeness, or usefulness of any information, apparatus, product, or process disclosed, or represents that its use would not infringe privately owned rights. Reference herein to any specific commercial product, process, or service by trade name, trademark, manufacturer, or otherwise, does not necessarily constitute or imply its endorsement, recommendation, or favoring by the United States Guvennent us any agency thereof. The views and opinions of authors expressed herein do not necessarily state or reflect those of the United States Government or any agency thereof."

This report has been reproduced directly from the best available copy.

Available from the National Technical Information Service, U. S. Department of Commerce, Springfield, Virginia 22161.

Price: Paper Copy $\$ 6.00$

Microfiche $\$ 3.50$ 
Introduction $\quad 1$

Reactor Design $\quad \cdots \quad 2$

Catalyst Preparation 3

Reactor System $\quad 5$

Results

TWR-Run 6

TWR-Run $7 \quad \therefore \quad$ Z

TWR-Run 8 . 8

TWR-Run 9

$\begin{array}{lll}\text { TWR-Run } 11 & 9\end{array}$

TWR-Run $16 \quad \ldots$

$\begin{array}{ll}\text { Summary } & 11\end{array}$

$\begin{array}{lll}\text { Acknowledgements } & 11\end{array}$

References $\quad \cdot 12$ 


\section{ILLUSTRATIONS}

FIGURE

PAGE

1. Multitube Reactor for Synthesis of High-Btu Gas. 14

2. Internally Coated Tube Wall Reactor. 15

3. Tube Wall Methanation Reactor. 16

4. Catalyst Activation Assembly. 17

5. Schematic of the Tube Wall Reactor System. 18

6. Reactor Conditions and Product Gas Characteristics for TWR-Run $6 . \quad 19$

7. Reactor Conditions and Product Gas Characteristics for TWR-Run $7 . \quad 20$

8. Reactor Cond1tions and Product Gas Characteristics for TWR-Run $8 . \quad 21$

9. Reactor Conditions and Product Gas Characteristics for TWR-Run $9 . \quad 22$

10. Reactor Conditions and Product Gas Characteristics for TWR-Run 11. 23

TABLE

1. Reactor Characteristics and Activation Parameters 24

2. Analyses of Catalyst Samples 25

3. Selected Test Data TWR-Run 6

4. Selected Test Data TWR-Run 7

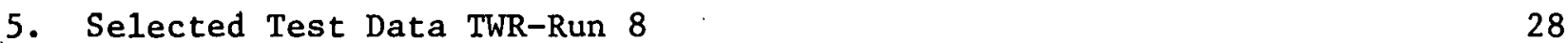

6. Selected Test Date TWR-Run 9.

7. Selected Test Data TWR-Run $11 \quad 30$ 


\title{
METHANATION IN CATALYST-SPRAYED TUBE WALL REACTORS: A REVIEW
}

\author{
H. W. Pennline, R. R. Schehl, W. P. Haynes, A. J. Forney \\ Pittsburgh Energy Technology Center \\ U. S. Department of Energy \\ Pittsburgh, PA 15236
}

\begin{abstract}
The design and operation of catalyst-sprayed tube wall reactors for methanation are discussed. Reactor tubes were either coated on the inner surface or on the outer surface with a Raney nickel catalyst. A liquid coolant, which was opposite the catalyst-reactant gas-side, removed the heat of methanation. Catalyst performance, reactor operating conditions, spent catalyst analyses, and other results are presented for five PDU tests.
\end{abstract}

\section{INTRODUCTION}

During the late $1960^{\prime} \mathrm{s}$, the U.S. Government and industry - concerned with a possible shortage of natural gas - began investigations for the development of efficient catalytic methanation reactors which are essential for the conversion of coal to substitute natural gas. Several different methanator designs have been studied at the Pittsburgh Energy Technology Center (PETC) of the U. S. Department of Energy [1-7]. A11 process development unit (PDU) designs have a very small pressure drop across the reactor and use flame-sprayed Raney nickel catalyst but differ in the methnd of heat removal. Advantagcs of tlie Lulue wall reaccor cype over other designs are the low recycle rate needed for heat removal and the combined functions of reactor and heat recovery in one vessel. The purpose of this communication is to report the development of the tube wall reactor design and the results of tests with PDU systems.

The tube wall reactor (TWR) is essentially a tube whose inside (or outside) wall has been coated with a catalytically active surface for methanation. This surface when exposed to a flow of synthesis gas is capable of efficient production of high-Btu substitute natural gas at high thermal efficiencies and low pressure drop. From the earliest conception of a tube wall bench-scale reactor [6-9], Raney nickel catalyst flame sprayed on a stainless steel substrate has been used almost exclusively. After activation of the catalyst and during operation, the heat of reaction was removed by conduction through the steel substrate to a reservoir of liquid coolant, Dowtherm. Initial scale-up work of this type involved a PDU-scale multitube reactor consisting of seven two-inch tubes, each externally sprayed with Raney nickel over a length of six feet. Satisfactory operation of two initial tests, TWR-Run 1 and TWR-Run 2, produced continued program interest in process parameters, alternate reactor design, and catalyst performance [10]. A slight variation of the multitube reactor was incorporated in tests TWR-Run 3, TWR-Run 4, and TWR-Run 5. The multitube reactor was only sprayed for 27 inches instead of 6 feet. These three tests were not extraordinary due to inadequacies and inexperience in the flame spraying and operation of the system. Excellent results were obtained in the next test (TWR-Run 6), and reactor design variation was thoroughly investigated thereafter. 


\section{REACTOR DESIGN}

Three different reactor designs were studied in the tube wall reactor PDU tests. All these continuous runs used 1) a $3 \mathrm{H}_{2}: 1$ CO synthesis gas which mixed with a dry recycle gas and entered the bottom of the reactor; 2) Dowtherm for heat removal; and 3) flame-sprayed Raney nickel catalyst. (58 percent aluminum, 42 percent nicke1). The principal differences were in the heat removal design which was directly related to the reactor geometry.

The tube wall reactor used in TWR-Run 6 and Run 8 was a multitube unit, as shown in Figure 1. The shell of the reactor was 8 -inch, schedule 40 stainless steel pipe, with an overall length of 11 feet. The unit contained seven catalyst tubes, each 2 inches in diameter by 7 feet long and placed on 2-1/2 inch centers. The outer surface of each tube was thermally sprayed with Raney nickel [11] over a length of 27 inches to give a total geometric catalyst surface area of $8.4 \mathrm{ft}^{2}$. Thermowells were mounted along the length of the catalyst surface of four tubes, and thermocouples were placed in each well. A calibrated and motorized drive moved the thermocouples to permit measurement of catalyst temperatures in 1-inch increments along the entire length of each of four sprayed tubes.

Each catalyst tube had a 1-inch diameter dip-tube down the center. During operation 1iquid Dowtherm passed down the dip-tube and then boiled as it passed upward through the annulus to remove the heat of reaction. The Dowtherm vapor entered the condenser above, was indirectly cooled and condensed with water, and then by gravity was fed back into the center tube. To achieve good contact between gas and catalyst, the coated lengths of the sprayed tubes were baffled so that the synthesis gas, as it passed upward through the reactor, was forced by the horizontal baffles to take a tortuous path across the tube surfaces. Thirteen baffles were placed 2-inches apart to divert the mixed synthesis gas flow across the coated tubes.

The reactor for TWR-Run 7 is illustrated in Figure 2. This test was to demonstrate the operabllity of a reactor having catalyst on the inner surface rather than on the outer surface of the reactor tube. Essentially it consisted of three sections made up of 4-inch schedule 40 type 304 stainless steel pipe; each section had been internally flame sprayed with Raney nickel powder over a length of 32 inches. Limitations inherent in the powder-fed metallizing gun at that time required a minimum I.D. of about 4-inches. A sealed 3-1/4 inch $0 . D$. stainless steel tube inside of the 4-inch reactor formed an annular gas space about 3/8-inch wide. Later, after 740 hours on stream, the reactor was modified by the installation of baffles on the outside of the annular. tube. The baffles were rings of 1/32-inch thick stainless steel sheet cut 3/16-inch wide and later spot-welded on the annular tube about 2-inches apart in the catalyst sections. Thermocouples in thermowells on the catalyst surface were assumed to measure the temperature of the catalyst, while others were positioned to provide a measure of the gas temperature.

The reactor pipe was jacketed by a 6-inch schedule 40 pipe that formed an annular space to contain Dowtherm. During operation the Dowtherm entered the bottom of the lower section and continued upward through each section, finally to be condensed and returned to the bottom section. The gas inlet was at the bottom of the reactor. 
The reactor used in TWR-Run 9 and Run 11 is shown in Figure 3 and consisted of a 2-inch schedule 40 pipe flanged on the ends and surrounded by a 4-inch schedule 40 jacket. All reactor material was 304 stainless steel. Raney nickel catalyst was flame sprayed onto the inner 2-inch pipe wall for fourteen feet of length. The reactor tube was partially filled by a 1-1/2-inch diameter, sealed tube to form a 1/4-inch wide annular cross. section for the reacting gases. In Run 11 , this sealed tube was removed after 271 hours. Dowtherm was added to the annular shell to remove the exothermic heat of reaction during the run. A reservoir, adjacent to the vertical reactor, was used as part of the Dowtherm vapor-liquid recycling system. The temperature of the saturated coolant was regulated by controlling the electrical resistance heating and the pressure of the cooling system.

Nucleate boiling took place on the outer surface of the reactor pipe, thereby providing a natural convective circulation of Dowtherm. The Dowtherm vapor was condensed by cooling water or air convection and returned to the reservoir. In a commercial plant the heat removed by the Dowtherm could be used to produce process steam.

Probes could be inserted into the reactor through the top and bottom flanged reactor heads. Three thermowells with thermocouples were inserted to get representative catalyst temperatures; the sample ports were machined so that the thermowells were against the catalyst surface and extended the length of the reactor. Thermocouples in the thermowells were positioned to obtain temperatures along the fourteen feet of catalyst length. Gas concentration profiles were obtained with stationary stainless steel tube gas probes positioned along the catalyst length.

A second stage reactor was usually put on stream when the catalyst in the primary reactor began to deactivate. The second stage reactor was a 3/4-inch schedule 40 pipe and was charged with a four foot long bed of cylindrical $\left(1 / 8^{\prime \prime} \times 1 / 8^{\prime \prime}\right)$ commenrcial nickel catalyst pellets to give the reactor a bed volume of $0.012 \mathrm{ft}^{3}$. The purpose of the second stage reactor was to test the ability of a commercial catalyst to reduce residual carbon monoxide coming from the first stage reactor to less than 0.1 percent by volume. The reactor was operated adiabatically, without gas recycle, and without removal of water vapor in the feed gas.

\section{CATALYST PREPARATION}

The reactor tubes were prepared by flame spraying Raney nickel catalyst onto the surface [12]. Bonding of the Raney nickel to the tube was generally good when the following procedure was used: first, the tube was initially grit blasted with virgin aluminum oxide granules prior to the first application of the bond coat. Thereafter, the reactor was grit-blasted to remove spent catalyst from the tube for subsequent flame spraying of fresh catalyst. Before application of the bond coat, the particular tube to be sprayed internally or externally should be preheated, and a heat transfer medium circulated on the coolant side of the reactor to distribute the heat input to the tube during spraying and prevent excessive, uneven thermal expansion in the tube. However, the jacket of the original 14 foot tube wall reactor in Run 9 was cut because of expansion stresses. The bond coat, nickel aluminide, was applied using an acetylene-oxygen flame and was sprayed to a thickness of $0.006 \pm .002$ inches. When internally sprayed, wire nickel aluminide ( $80 \% \mathrm{Ni}, 2 \overrightarrow{0 \%} \mathrm{Al})$ 
was fed to a spray gun equipped with a rotary gun extension, but powdered bond material (95\% $\mathrm{Ni}, 5 \% \mathrm{Al}$ ) was directly deposited onto a pipe when externally sprayed.

Before application of the catalyst, the tube should again be preheated, and a heat transfer medium should be circulated on the non-coating side of the reactor. Raney nickel (42 wt percent $\mathrm{Ni}, 58 \mathrm{wt}$ percent $\mathrm{Al}$ ) was deposited to a thickness of $0.025 \pm .002$ inches by the use of a hydrogen-oxygen flame. For external spraying, powdered Raney nickel between 80 and 200 mesh was deposited onto the substrate. A simflar size catalyot was used for internal spraying except that a wire consisting of Raney nickel powder mixed with a polyethylene/polypropylene binder was fed into the spray gun.

In the externally sprayed experiment, kun 6, new tubes were used, and the initial surface was prepared by sandblasting. After a bond coat was laid down, a freshly ground Raney nickel powder, mesh size 80-200, was flame sprayed to a thickness of about 20 mils. The overall geometric coating was $8.4 \mathrm{ft}^{2}$ where geometric catalyst area is the external surface of the catalyst and not the B.E.T. area. Run 8 was identical to Run 6 . The same mesh size of catalyst was sprayed on the same cleaned tubes of Kun $\dot{b}$.

Runs 7, 9, and 11 were all internally sprayed. In Run 7, a catalyst powder, again 80-200 mesh size, was sprayed to a thickness of about 20 mils onto three sections of 4-inch pipe. The total area was $8.33 \mathrm{ft}^{2}$. Runs 9 and 11 consisted of a 14 foot internally sprayed 2-inch schedule 40 pipe. The Raney nickel catalyst powder, 80-200 mesh, was mixed with a polyethylene/polypropylene binder, extruded into wire form, and fed to a special spray gun. The reactor in Run 9 was reused in Run 11. Also, a heavier coating of Raney nickel was applied in Run 11 than in Run 9. The spraying thickness and weight of catalyst in Run 9 were $19 \mathrm{mil}$ and $434 \mathrm{gm}_{2}$ respectively. The geometric catalyst area in both runs was about $7.4 \mathrm{ft}^{2}$. Table 1 lists the characteristics of each reactor.

After spraying, each reactor was vertically placed in the carbon steel system and leached in situ. Since catalytic activity is directly related to surface area, a very porous layer of nickel is desired. This is accomplished by reacting the aluminum in the Raney nickel alloy with a 2-weight percent solution of ACS-grade sodium hydroxide. The gravityfed system is shown in Figure 4. Before the caustic flow was started, the reactor was filled with deionized water. The extent of activation was determined by metering the amount of hydrogen evolved according to three moles of hydrogen for every two moles of aluminum reacted. The reaction was stopped when about 70 percent of the theoretical amount of aluminum in the Raney alloy was reacted. Heat was occasionally added to speed the reaction. In past experience, the unleached Raney nickel substrate acted as an adhering agent between the leached catalyst and the bond coat.

When leaching was finished, the reactor was drained under a helium atmosphere, and a continuous stream of deionized water was flowed over the catalyst. The question arises whether the reactor in Run 6 was drained under helium. Many times during the rinsing procedure, the catalyst was batch flushed with this water always under a helium atmosphere. Sometimes traces of spalled catalyst were found in the effluent water. Washing was stopped when the $\mathrm{pH}$ of the rinse water was approximately the same as that of the demineralized water. The leaching apparatus was dis- 
assembled and the reactor was incorporated into the system; all steps were performed under a helium flow. The reactor system was then placed under hydrogen until the temperature and pressure were brought to synthesis conditions, at which time the synthesis feed gas was gradually fed into the system to. start the run. Pertinent catalyst bed data are shown in Table 1.

\section{REACTOR SYSTEM}

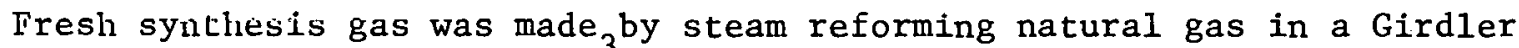
plant and was stored in $60,000 \mathrm{ft}^{3}$ holders until needed. The gas was compressed to 500 psi, passed through a silica gel'trap for dehumidification, and then passed through two carbon traps in series to remove sulfur compounds, which can poison the nickel catalyst. Sulfur concentrations were detected by the methylene blue method. The concentration of total sulfur entering the reactor system was usually found to be about $20 \mathrm{ppb}$ in each of the runs except at the end of TWR-Run 6 . The hydrogen-to-carbon monoxide ratio in the synthesis gas ranged from $3.0: 1$ to $3.3: 1$ and there was usually a slight excess of hydrogen in the synthesis gas to prevent possible carbon deposition.

A schematic flowsheet of a typical reactor system is shown in Figure 5, where the mixed feed gas to the reactor is preheated by a series of three heat exchangers. The first exchanger is steam-heated, the second exchanger recovers sensible heat from the hot product gas, and the third is heated by Dowtherm vapor. Product water is condensed from the product gas stream; then part of the dry product gas is returned to the feed gas stream.

During the test, volumetric gas samples which were representative of a 24-hour period were analyzed by both mass spectrometry and gas chromatography. An online gas chromatograph checked sample results. The gas analyses, the condensed product water weights, and metered flows were used to calculate the mass balances for each 24-hour period.

\section{RESULTS}

\section{TWR-Run 6}

Experiment TWR-Run 6 successfully completed 2868 hours of operation of a multi-tube tube-wall reactor using flame sprayed Raney nickel catalyst [13]. The reactor contained seven 2-inch diameter tuhes, each tube coated with catalyst 27 inches in length for $8.41 \mathrm{ft}^{2}$ of geometric catalyst surface area. Product gas yield was $232,000 \mathrm{scf} / 1 \mathrm{~b}$ of sprayed catalyst. Experiment TWR-Run 6 operating conditions and results are shown in Table 3 for the early part of the test and near the end of the test. Figure 6 is a graphical representation of the reactor conditions and product gas characteristics throughout the entire experiment.

The fresh feed was maintained at an exposure velocity of 60 ( 1 unit exposure velocity $=1 \mathrm{SCFH}$ of synthesis gas per square foot of catalyst surface area) throughout the run except at the very end when it was dropped to a 50-exposure velocity level. The cold recycle ratio was held at $3: 1$ except when it was increased at the experiment end. The maximum catalyst temperature averaged about $390^{\circ} \mathrm{C}$. System pressure was held at a constant 300 psig. 
Product gas results indicate a gradual poisoning of the catalyst with time as shown by the increase of $\mathrm{CO}$ in the product gas with time. Three shutdowns at 93, 1154, and 2361 hours on stream did not appear to additionally deactivate the nickel catalyst. Extra hydrogen was added to the system when starting up. Product gas was recycled until the catalyst was cooled during shutdown. The heating value of the product gas ranged between $825-900 \mathrm{Btu} / \mathrm{scf}$ of product gas.

Several precautions which were unique to this test were undertaken in the physical preparation of the catalyst coated tubes and in the experimental operations. Unlike previous tests, new tubes were used. Initial surface preparation was by sandblasting only over the area to be coated with catalyst. A steel grit was used in previous experiments and the entire tube was cleaned with the steel grit. Presence of resldual steel grit may have been a contributing factor in carbon formation noted in previous tests $[14]$.

During operation sulfur concentratlon in the feed gas was maintained as low as possible, generally less than $20 \mathrm{ppb}$. Extraneous 1ron was kept from entering the system, thereby reducing the possible formation of carbon. Catalyst temperatures were prevented from exceeding $400^{\circ} \mathrm{C}$ or dropping below $380^{\circ} \mathrm{C}$. Previous testing allowed the maximum temperature to be as high as $415-420^{\circ} \mathrm{C}$. Also, carbide formation was minimized by using excess hydrogen in the feed gas during normal synthesis. The $\mathrm{H}_{2}$ : $\mathrm{CO}$ ratio in the feed ranged from 3.2 to 3.3 instead of the stoichiometric value of 3.0 .

The performance of the catalyst in Run 6 declined very slowly until the last 300 hours of operation. During that period, the sulfur content of the feed gas rose steadily to a maximum of $0.35 \mathrm{ppm}$, and the catalyst activity declined rapidly. Although chemical analysis of the spent catalyst failed to show any increase in sulfur content of the catalyst, the coincident loss of activity with large increases in sulfur cuncentration in the feed gas suggests that loss of catalyst activity may have been caused by sulfur poisoning.

Inspection of the catalyst-coared cubes seveded that conjidcrablo spalling had taken place and loose catalyst had accumulated on the baffles and in the bottom of the reactor shell. Analysis of unactivated flame-sprayed Raney nickel and of spent Raney nickel from the experiment is shown in Table 2. The iron and carbon concentrations in the spent catalyst were signiflcantly higher than those of the fresh flame-sprayed catalyst and were higher in the catalyst located at the gas inlet end than in the catalyst located near the outlet. Fresh catalyst contained no carhon.

Decomposition of iron carbonyl is the suspected source of the deposited iron. The iron, in turn, promotes carbon formation and possibly carbide formation. According to the X-ray analysis, the bulk of the spent Raney nickel catalyst along the entire length of the catalyst tubes was nickel carbide. Changes in catalyst BET surface area. from inlet end to outlet end were smal1, ranging from 33.9 to $31.4 \mathrm{~m} / \mathrm{gm}$. 


\section{TWR-Run 7}

Experiment TWR-Run 7, after 1175 hours of operation, successfully demonstrated the operability of a tube wall reactor having Raney nickel catalyst on the inner surface rather than on the outer surface of the catalyst tube. Reactor performance was lower than that obtained in the previous test. The catalyst surface area was $8.3 \mathrm{ft}^{2}$ or essentially the same as the calculated area available in the multi-tube reactor used in Run 6.

After activation of the Raney nickel catalyst, the unit was put on stream with synthesis gas containing about 3.2 parts of hydrogen to 1 of carbon monoxide at 300 psig system pressure. Initial fresh gas feed rate was a 60-exposure velocity with a recycle-to-fresh-gas ratio of 3 . At this feed rate, the unreacted $\mathrm{CO}$ in the product gas exceeded the desired limit of about 2 percent; therefore, after only 8 hours duration, the fresh gas exposure rate was lowered to a value of about 25 . Average catalyst temperature, recycle ratio, and $\mathrm{CO}$ percent in product gas are presented in Figure 7, and representative data are shown in Table 4.

During the first 300 hours of operation, the response of the catalyst to Lemperature was tested. Using the concentration of carbon monoxide in the tail gas as an indicator, this value remained essentially the same at 1.2-1.4 percent while the average temperature was varied over the range $387^{\circ}$ to $404^{\circ} \mathrm{C}$.

Over the period of 330 to 500 hours of operation, the recycle ratio was reduced from 3 to 0 . This change reduced $C O$ in the product gas significantly from 1.3 to about 0.1 percent.

After 513 hours operation, the filter in the gas inlet line became plugged with carbon; this required a shutdown to remove the carbon. Shutdowns which were due to operational difficulties or were planned occurred at $361,513,740,809,1029$, and 1123 hours on stream. Reactor performance appeared not to be influenced by these shutdowns during the run.

At the end of 740 hours on stream, the reactor was modified by the installation under helium of baffles on the outside of the $3-1 / 4-i n c h$ $0 . D$. annular tube. The baffles were rings of $1 / 32$-inch thick stainless steel sheet, 3/16-inch wide. They were spot-welded onto the annular tube about 2 inches apart in the catalyst sections. Over the period from 568 hours to 740 hours at a 3 to 1 recycle ratio, the Co concentration in the product gas was 1.4 to 1.5 percent. At similar conditions, after the installation of the baffles in the period from 880 hours to 975 hours; the value was about 1.7 percent. Thus, the baffle installation brought no improvement in performance.

After 1029 hours on stream, in an attempt to regenerate the catalyst which had started to lose activity rapidly, the unit was operated on hydrogen for 47 hours at 300 psig system pressure and at a temperature of about $380^{\circ} \mathrm{C}$. No improvement in slowing the loss of activity could be observed as a result of the hydrogen treatment. The experiment was terminated after 1175 hours operation.

The spent catalyst was physically sound. Results of analysis are in Table 2. Chemical analysis indicates a greater percentage of carbon at the inlet (reactor bottom) than at the product exit. X-ray diffraction 
results show only cubic nickel present. However, loose catalyst found at the reactor bottom during reactor modification at 740 hours showed the presence of nickel carbide.

From surface area analysis, a larger surface, area $\left(31.43 \mathrm{~m}^{2} / \mathrm{gm}\right)$ existed at the reactor entrance than at the exit $\left(14.07 \mathrm{~m}^{2} / \mathrm{gm}\right)$. Also, smaller pore radii and volumes were found at the entrance as compared to the exit. This would indicate that perhaps carbon with its small molecular size was present at the reactant gas entrance.

\section{TWR-Run 8}

Experiment TWR-Run 8 again used the multi-tube tube wall reactor. The purpose of this test was to repeat experiment TWR-Run 6 that successfully ran for over 2800 hours and thus establish the general reliability and reproducibility of operation of the tube wall methanation system. Results for the first 750 hours of operation for experiment TWR-Run 8 indirated that reactor performance of experiment Run 6 was successfully repeated.

The run was terminated after 1681 hours on stream as the catalyst activity decline became more pronounced. The graph in Figuite 8 illustrates the declining catalyst activity with time, as expected, during the initial period of the test with all conditions constant. An increase in exposure velocity from 60 to 75 to 90 accelerated the deactivation of the catalyst. With a constant high feed rate, a decrease in the recycle ratio seemed to enhance $C O$ conversion. This result is not clear due to the variation of several process variables simultaneously. Shutdown at 575, 1441, 1583, and 1585 hours. on stream did not affect catalyst activity. All startups were performed in excess hydrogen. Maximum catalyst temperature during the run ranged between $388^{\circ}-395^{\circ} \mathrm{C}$ and pressure was a constant 300 psig. Selected periods are shown in Table 5.

The run was temporarily shut down after 1441 hours on stream as the catalyst activity decline became more pronounced. An inspection of the coated tubes indicated that one of the tubes suffered from flaking of $f$ of ndd-shaped catalyst pieces over the entire coated length. The lower section of all seven tubes was badly blistered. This lower section is contacted first by the reacting gases. In addition, considerable loose catalyst was lying on the baffles. The catalyst on the upper $75-80 \%$ of the six tubes appeared to be in good condition. Results by x-ray analysis of catalyst samples in Table 2 indicated that nickel carbide was formed at the reactant gas inlet.

At 1583 hours on stream, the catalyst was oxidized in a regeneration attempt. Air and nitrogen were mixed to obtain $3-3.5$ percent oxygen in nitrogen. The catalyst was exposed to this gas mixture at $400^{\circ} \mathrm{C}$ and 6 SCFH total for 69.5 hours. Subsequent testing did not indicate an improvement in catalyst activity.

The spent catalyst was analyzed at the end of the run also. Visual inspection indicated blistering of the catalyst near the center section of the catalyst area. Samples were taken at every third of the tube bundle length and analytical results are summarlzed in Table 2. Chemical constituents appear to have uniform composition along the length of the reactor within the analytical limits of uncertainty. However, analysis of loose material gathered from a bottom baffle at the end of the run shows a high carbon content $(2.0 \%)$. X-ray analysis further con- 
firms a faint pattern of $\mathrm{Ni}_{3} \mathrm{C}$. Samples scraped from the reactor do not show $\mathrm{Ni}_{3} \mathrm{C}$. Surface area, pore volume, and pore radii for each sample are all in the same range.

\section{TWR-Run 9}

Experiment TWR-Run 9 demonstrated the feasibility of internally coating and operating a 2-inch diameter by 14 foot long catalytic reactor tube. The technique of flame spraying the inner surface of the 2-inch nominal size tube wall reactor was made possible by the development of (1) a wire gun extension permitting a single pass traverse of 8 feet, and (2) extrusion of the Raney nickel catalyst powder with a polyethylene/polypropylene binder into a 1/8-inch diameter wire form. Details of the internally coated 2-inch tube wall reactor used for Run 9 were discussed previously.

The tube wall reactor was operated 653 hours with a $3 \mathrm{H}_{2}$ to 1 co synthesis gas, 300 psig system pressure, recycle to fresh gas ratios between 1 and 5 , and catalyst surface temperature in the $380-395^{\circ} \mathrm{C}$ range. Temperature control was excellent. Reactor conditions and product gas characteristics are shown in Figure 9 , and selected periuds are listed in Table 6.

Exposure velocity was maintained at 60 throughout. the experiment. Catalyst activity declined rapdily. Carbon monoxide in the product gas increased to 1.5 percent in the first 400 hours. The recycle ratio was then decreased to 1 and the $C O$ percent increased. A later increase to a recycle ratio of 5 slowed the deactivation rate which still continued to increase.

After 577 hours on stream, an attempt to reactivate the catalyst by oxidation was made. A total flow of about 6. SCFH of a nitrogen-and-airmixture with an oxygen concentration between 3-4 percent was passed over the catalyst at approximately $300^{\circ} \mathrm{C}$. This lasted for 47 hours. Later the system was purged and hydrogen was recycled until catalyst operating temperatures were reached, at which time synthesis gas was introduced into the system. : However, the catalyst regeneration attempt proved futile.

One possible cause for the poor performance of the reactor was that the amount of catalyst deposited by flame spraying was less than desired. Chemical results of spent catalyst as shown in Table 2 indicate a larger carbon percent at the reactant gas inlet $(3.8 \%)$ than at the exit $(1.2 \%)$. The iron composition was uniform along the bed but was far greater than that found inherently in Raney nickel.

By $X$-ray diffraction techniques, spent catalyst scrapings from the reactor bottom (gas in.1et) show a large amount of nickel carbide; whereas scrapings from the top indicate only a trace of nickel carbide. The Xray results corroborate the carbon found by chemical analysis.

\section{TWR Run-11}

The internally sprayed tube wall reactor used in Run 9. was resprayed and put into methanation service for Run 11. The catalyst was Raney nickel, sprayed to give a coating length of 14 feet. A heavier non-uniform coating of the Raney nickcl was applied for Run 11 than for Run 9, and it is suspected that some of the catalyst separated from the wall 
during the leaching operation. It is postulated that methanation occurred at very high temperatures on the loose, uncooled catalyst in the reactor bottom (gas inlet) and caused carbon to form which, in turn, plugged the reactor after 271 hours of operation.

The synthesis feed gas to the reactor was stopped at 116 and 271 hours on stream due to operational difficulties and at 679 hours for vacation. In each case, the catalytic system was heated and pressurized under hydrogen to methanation conditions before fresh gas was re-introduced to the catalyst.

During the first 271 hours of the test, a 1-1/2 inch 0.D. filler tube that was placed within the catalyst tube resulted in a 1/4-inch wide annular path for the gas flow. During the remainder of the operation, after the carbon plug was temuved, the filler tube was rommerl to give essentially a circular cross-sectional area for gas flow.

Figure 10 shows the conditions of operation and the product gas characteristics. Up unti1, 271 hours, the annular plug was in the reactor. At a constant exposure velocity of 30 , a decrease in the recycle did not appear to affect the $\mathrm{CO}$ in the product gas. However, the initial catalyst performance was not as good as that in Run 9.

After the shutdown when the plug was removed, the reactor was tested at 30-exposure velocity until 500 hours. After 325 hours on stream, a reduction of the recycle ratio from $3: 1$ to $1: 1$ resulted in a significant decrease in co concentration in the product gas. This trend suggests that at a constant feed rate the tube wall reactor performs more efficient $1 \mathrm{y}$ at low linear veloclties than at high linear velocities.

Exposure velocity was increased to 45 at a 0.5 recycle ratio. The catalyst performed poorly until the fresh gas rate was cut back to the 30-exposure velocity leve1. The experiment was terminated after 850 hours on stream. Data are shown in Table 7 .

The spent catalyst remaining on the inside of the 2-inch pipe reactor after shutdown was recovered by wire brushing. Analytical results are found in Table 2. Chemical analysis indicated that the percentage of iron in the spent sample $(0.7 \%)$ is somewhat greater than that found in unactivated Raney nickel. Carbon content was greater (1.7\%) in the spent catalyst and may have resulted from the carbon plug formed at 271 hours on stream. Chemical analysis of this plug material indicates a large percentage of iron. X-ray diffraction results of the final spent catalyst show only a pattern of metallic nickel.

Later internal flame spraying of the 2-inch reactor used a heat transfer liquid to equalize expansion and contraction stresses between the pipe and its jacket. In Runs 9 and 11, the problem of thermal expansion was dealt with by cutting the jacket and allowing the 2-inch pipe to expand and contract freely during the flame spraying after which the jacket was sealed by welding. For large-scale reactors it is important that a way be available to equalize the temperature of the reactor tube being flame sprayed with that of the other reactor tubes and the enveloping jacket. 
The last tube wall reactor test to be conducted was TWR-Run 16. This test was conducted with several modifications to the system. The annular tube in the internally sprayed reactor was not used because of the good catalytic performance attained in Run 11 after the tube was removed. The gas inlet to the reactor was at the reactor top instead of bottom. Any catalyst which may have fallen from the reactor could not come in contact with the reactant gases and form a possible carbon plug. Reactor inlet and outlet lines were washed and cleaned with a hot trisodium phosphate solution and flushed with water before the start of Run 16 . Test1ng was done at various flow parameters and lasted for 1179 hours on stream. Results are discussed in detail in a previous paper [3].

\section{SUMMARY}

The development and experimental results of the tube wall reactor designs have been chronicled. Advantages of this methanator type are the combined functions of reactor and heat recovery in one vessel and the low or even zero recycle rate needed for temperature control. Pressure drop across the reactor is negligible. The Raney nickel catalyst was very active, and results could be reproduced ac chown in Run 6 and 8 .

Optimum design, catalyst spraying technique, catalyst performance, and economics will determine whether the internally or externally coated reactor would be used in future scale-up to a commercial-size plant. The externally sprayed reactors have displayed excellent catalyst performance and the actual spraying is not difficult. However, in a large plant with a multi-tube reactor, respraying of the bundles after eventual catalyst deactivation would be difficult and would entail a complicated reactor design.

The internal spraying of catalyst is difficult and the test results have never been as good as external spraying. Battelle Columbus Labs, under contract to DOE, conducted studies to improve the catalyst spray gun [15]. In a commercial-scale plant, internal respraying of a tube bundle would be simple if a reliable and efficient gun was developed.

An extension of the above experimentation has been made in reactor modeling [16-19], in economic studies [20, 21], and in scale-up work for a coal to SNG plant [22]. Recent work done at PETC has incorporated tube wall reactors with Fischer-Tropsch synthesis [23, 24]. A conceptual design for a commercial-scale Fischer-Tropsch plant has been done by R. M. Parsons Company [25] and includes catalyst sprayed tube wall technology.

\section{ACKNOWLEDGEMENTS}

The authors wish to acknowledge the following people for their input to the project: J. J. Elliott, J. P. Strakey, G. J. Cinquegrane, and A. J. Youngblood. 


\section{References}

1. Haynes, W. P., Forney, A. J., Elliott, J. J. and Pennline, H. W., 1975. Synthesis of Methane in Hot Gas Recycle Reactor Pilot Plant Tests. ACS Div. of Fuel Chem. Preprints, 19(3):10.

2. Schehl, R. R., Pennline, H. W., Strakey, J. P. and Haynes, W. P., 1976. Pilot Plant Operation of a Nonadiabatic Methanation Reactor. ACS Div. Fuel Chem. Preprints, $21(4): 2$.

3. Pennline, H. W., Schehl, R. R. and Haynes, W. P., 1979. Operation of a Tube Wall Methanation Reactor. Ind. Eng. Chem. Proc. Des. Dev., 18(1):156.

4. Strakey, J. P., Forney, A. J. and Haynes, W. P., 1975. Methanation in Coal Gasification Prócesses. ERDA PERC/IC $=75 / 1$.

5. Pennline, H. W.; SchehI, R. R. and Haynes; W. P., 1978. Efficient Methanation in Coal Gasification. Coal Processing Tech., Vol. 4.

6. Fịeld, J. H., Demeter, J. J., Forney, A. J. and Bienstock, D., 1964. Deyelopment of Catalysts and Reactor Systems for Methanation. Ind. Eng. Chem, Prod, Res, Dey, , 3(2):150.

7. Demeter, J. J., Youngblood, A. J., Field, J. H. and Bienstock, D., 1967. Synthesis of High-Btu Gas in a Raney Nickel Coated Tube Wall Reactor. Bur. Mines R.I. 7033.

8. Sayinell, R. F., Youngblood, A. J. and Haynes, W. P., 1976. Results and Analysis of Three Experiments in a Bench-Scale Tube-Wall Methanation Reactor. ERDA PER,C/RI-76/4.

9. Forney, A. J., Haynes, W. P., E1liott, J. J. and Kenny, R. F., 1972. Clean Automotiye Fuel: Laboratory-Scale Operation of the SYNTHANE Process. Bur. Mines TPR/49.

10. Haynes, W. P., Elliott, J. J., Youngblood, A. J. and Forney A. J., 1970. Operation of a Sprayed Raney Nickel Lube Wa11 Reactor for Production of a High Btu Gas, ACS Div. Fuel Chem. Preprints, 14(4).

11. O'Hare, S, A., O'Brien, W: L., Worthington, R. B. and Mausser, J. E., 1976, Powder Metallurgy of Raney Nickel. Bur. Mines RI 8182.

12. Cịnquegrane, G. J., Schehl, R. R., Strakey, J. P. and Haynes, W. P., 1976. A Description of the Method of Producing Coatings of Raney Nickel Catalyst by Flame-Spraying and Findings Obtained by Examining Samples of the Coatings. Presented at Catalytic Materials Symposium, Materials Research Society, Cambridge, Mass.

13. Haynes; W, P, Elliott, J, J. and Forney, A. J., 1972. Experience With Methạnation Cạtalysts, ACS Diy. Fuel Chem. Preprints, 16(2):47. 
14. Schehl, R. R., Pennline, H. W., Youngblood, A. J., Baird, M. J., Strakey, J. P. and Haynes, W. P., 1977. Deactivation of Raney Nickel Methanation Catalyst. ERDA PERC/RI-7]/10.

15. Roseberry, T. J., Clare, J. H. and Caudy, D. L., 1979. Flame Spraying of Catalyst. Battelle Final Report, DOE Contract No. W70405 Eng 92 Task Agree. No, 75, Amend. No. 2.

16. Ralston, T. D., Haynes, W. P., Forney, A. J. and Scheh1, R. R., 1974. Tube-Wall Methanation Reactors with Combined Diffusion and Kinetic Resistance, Bur. Mines R.I. 7.941.

17. Scheh1, R. R., Weber, J. K., Kuchta, M. J. and Haynes, W. P., 1977. Application of a Diffusion Limiting. Model to a Tube-Wall Methanation Reactor. Ind. Eng. Chem. Proc. Des. Dev, , 16(2):227.

18. Senkan, S. M., Evans, L. B. and Howard, J. B., 1976. An Analysis of the Tube-Wa11 Reactor Under Diffusion Limiting Conditions. Ind. Eng. Chem. Proc. Des. Dev., 15(1):184.

19. Șenkan, 3. M., Evans, L. B. and Howard, J. B., 1979. An Analysis of Wall-Supported Catalyst Structures. Ind. Eng. Chem. Proc. Des. Div., 18(I): 125.

20. Forney, A. J,, Gasior, S. J., Haynes, W. P. and Kate11, S., 1970. A Process to Make High Btu Gas From Coal. Bur. Mines TPR 24.

21. Furney, A. J., Kate11, S. and Crentz, W. L., 1970. High-Btu Gas From Coal via Gasification and Catalytic Methanation. Proceedings of the Amer Power Conference, Yol. 32 .

22. Wei, V. T. and Chen J., 19.74. Methanator for Coal Gasification. Coal Processing Tech., Vol. 1.

23. Haynes, W. P., Baird, M. J., Scheh1, R. R, and Zarochak, M. F., 1978. Fischer-Tropsch Studies in a Bench-Scale Tube Wall Reactor Using Magnetite, Raney Iron, and Taconite Catalysts. ACS Div. Petroleum Chem. Preprints, $23(2): 559$.

24. Berty, J. M., 1979. Analysis of Process Development Reactor Design for the Thermal Performance on the Cooling Side for the Fischer-Tropsch Process. DOE Contract No, DE-AP22-79PC10812.

25. O'Hare, J. B,, Bela, A., Jentz, N. E., Khaderi, S. K., Klumpe, H. W., Loran, B. I., Reynolds, D. G. and Teeple, R. V., 197.7. . Fischer-Tropsch Complex Conceptual Design/Economic Analysis. ERDA Contract No. E(49-18)-1775. 


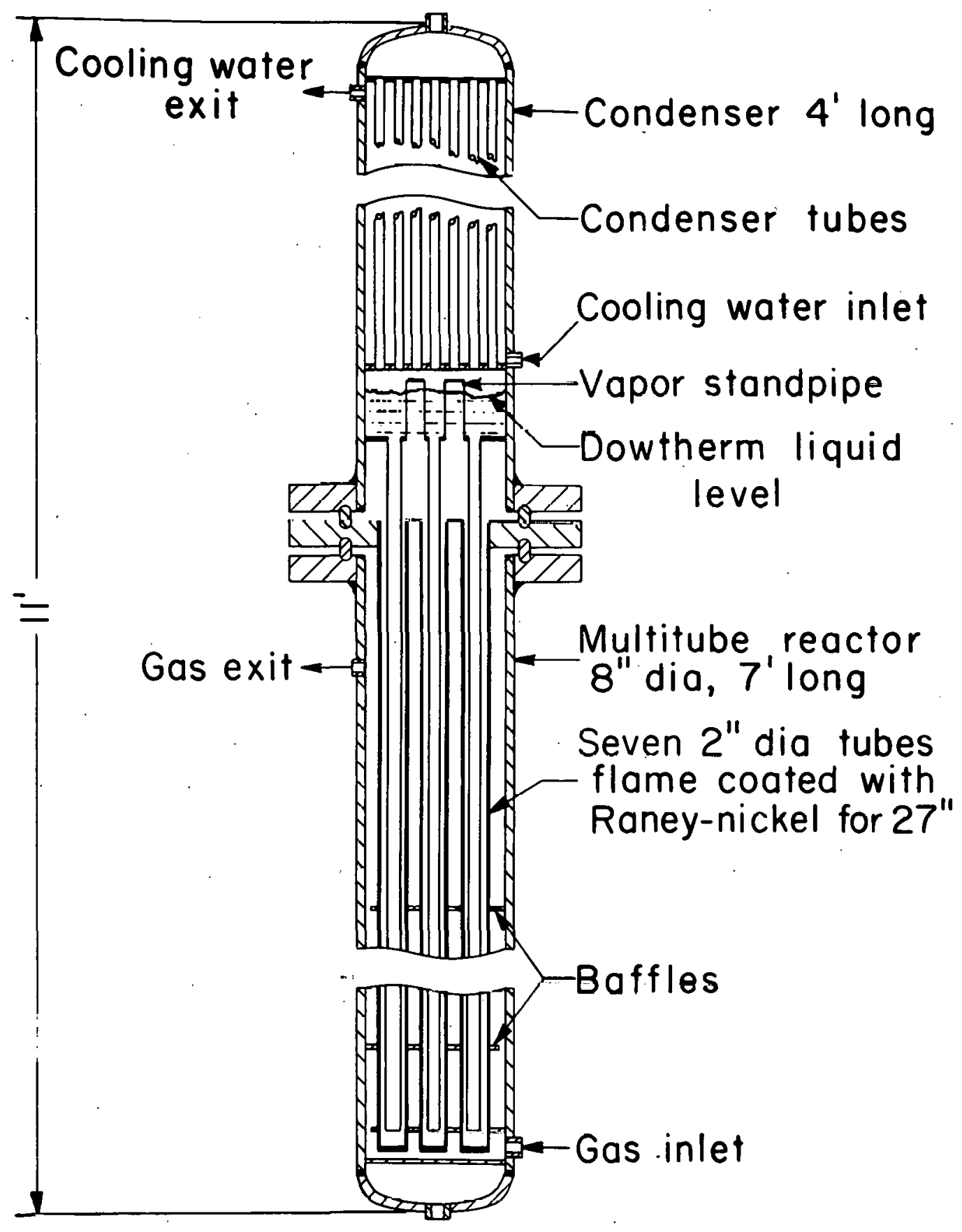

Figure 1: Multitube Reactor for Synthesis of High-Btu Gas

$$
\text { 10-2-79 L-9196 }
$$




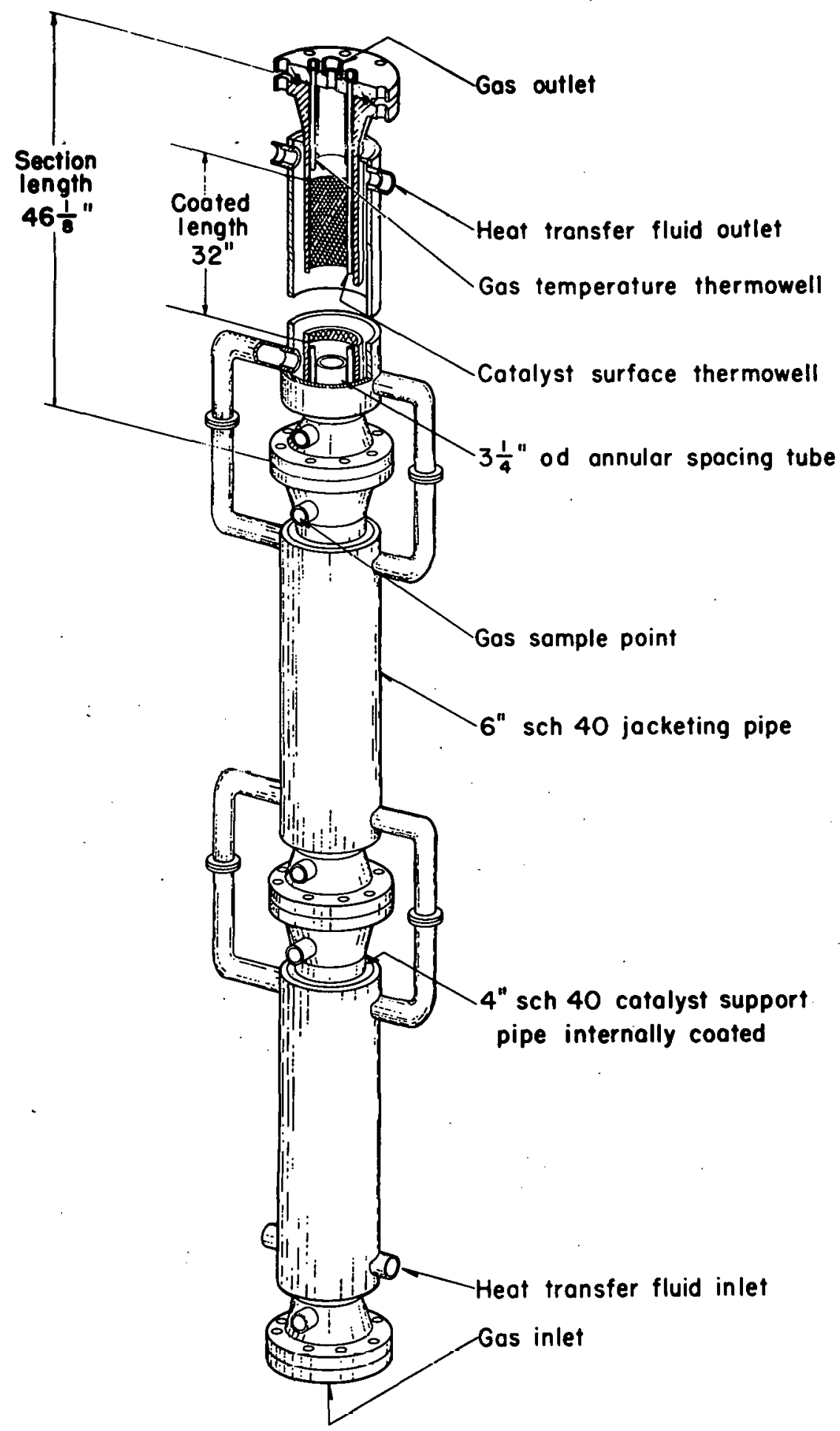

Figure 2: Internally Coated Tube Wall Reactor

$$
10-2-79 \quad L-12404
$$




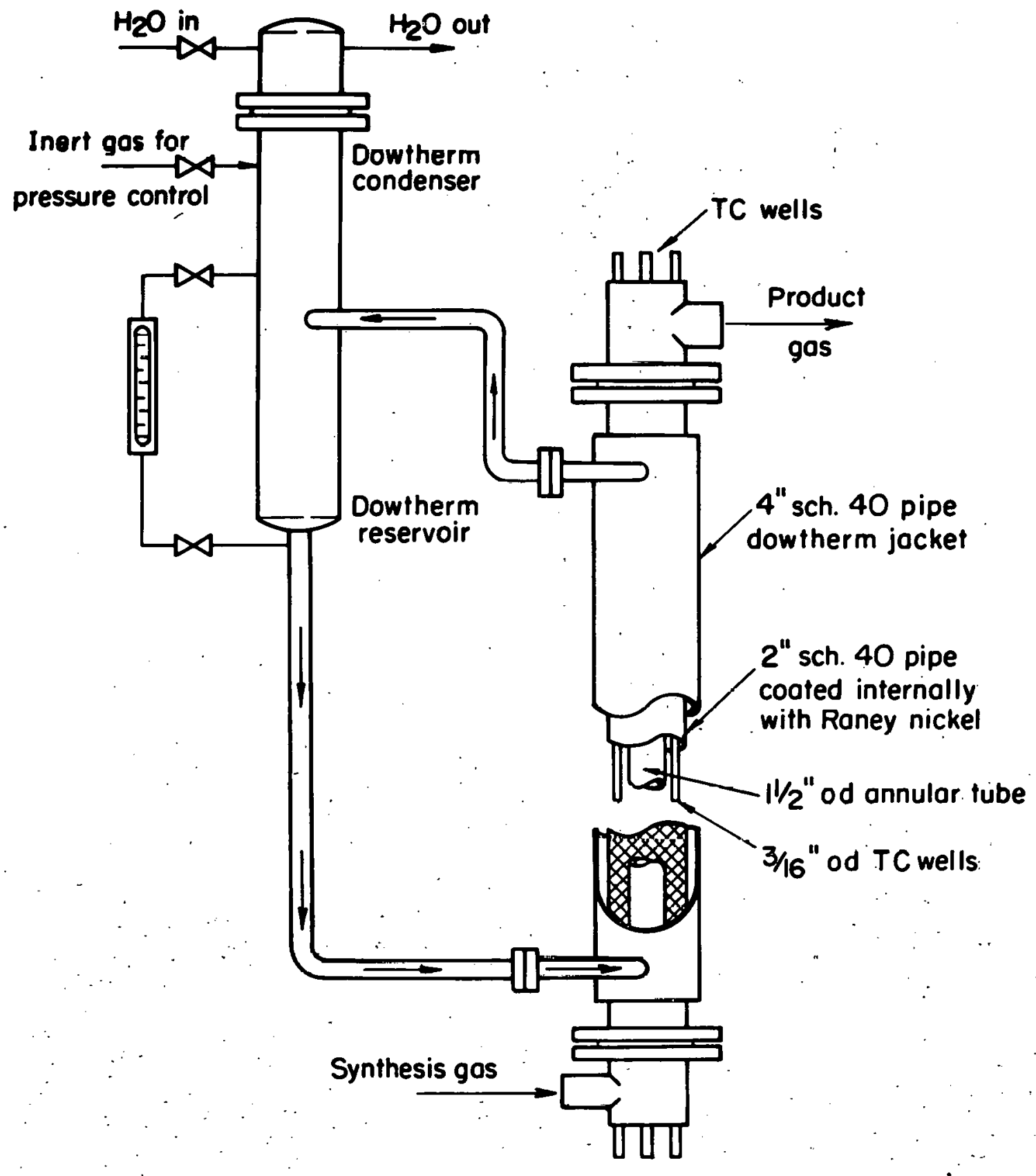

Figure 3: Tube Wall Methanation Reactor 


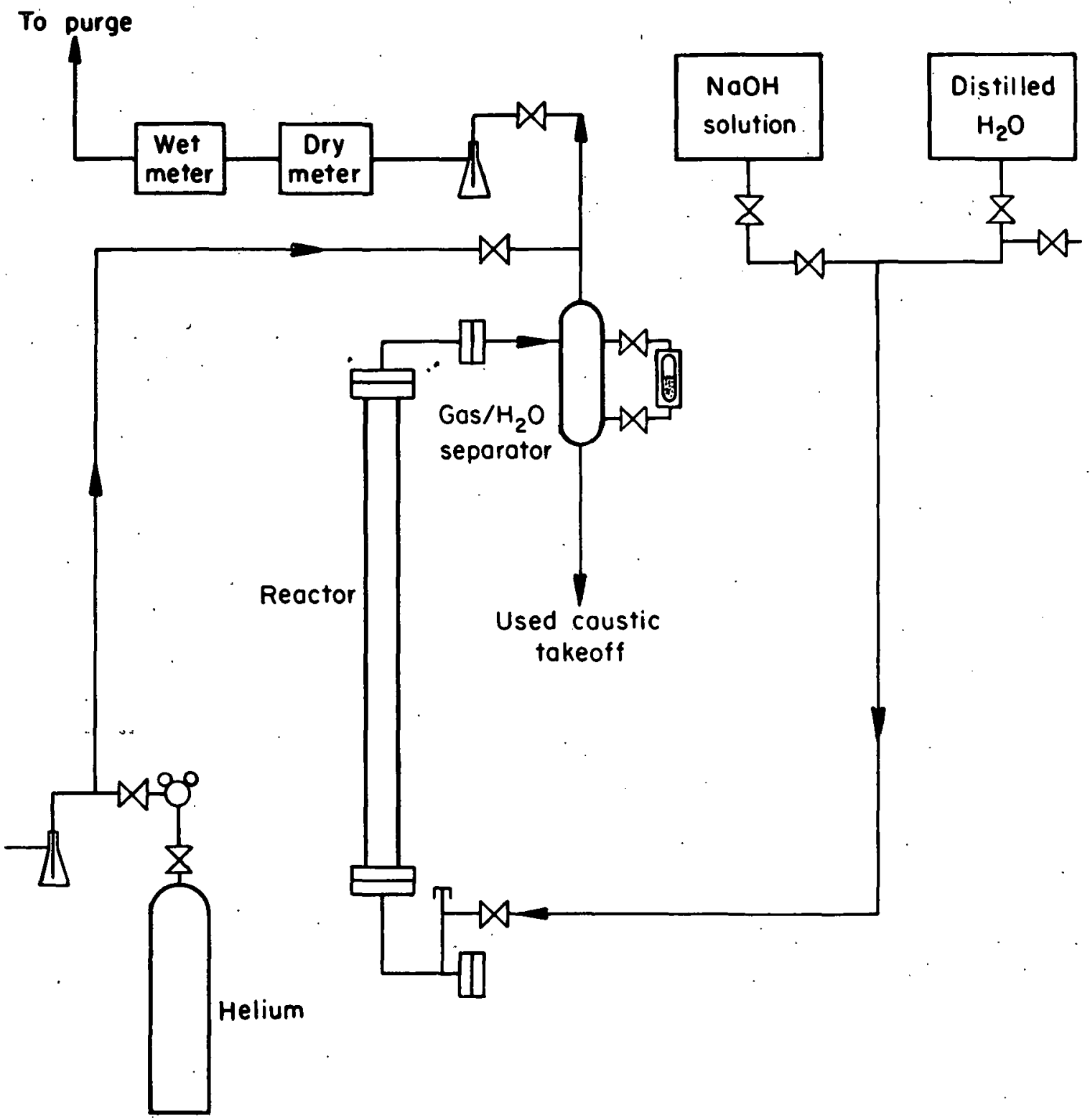

Figure 4: Catalyst Activation Assemb1y 


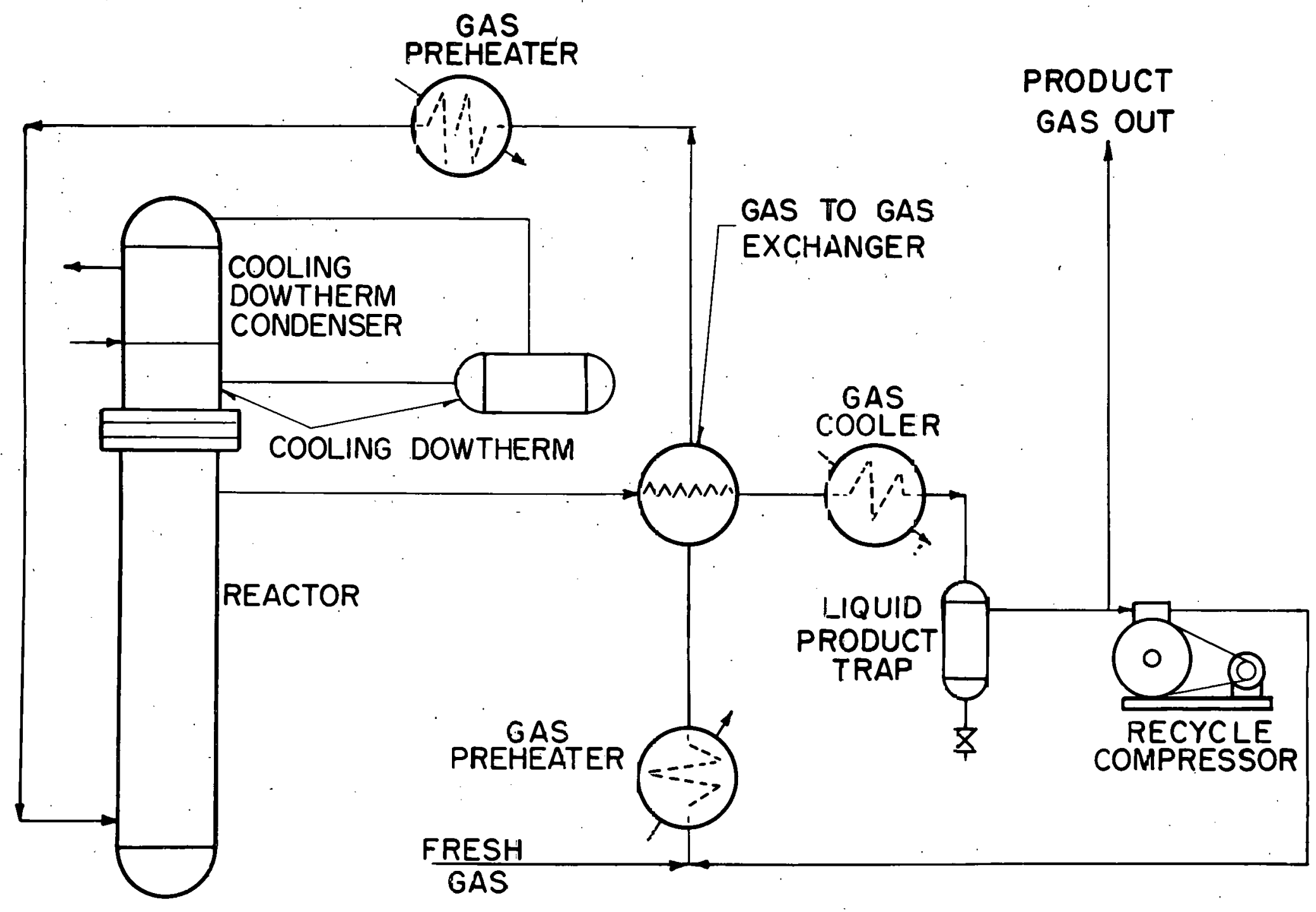




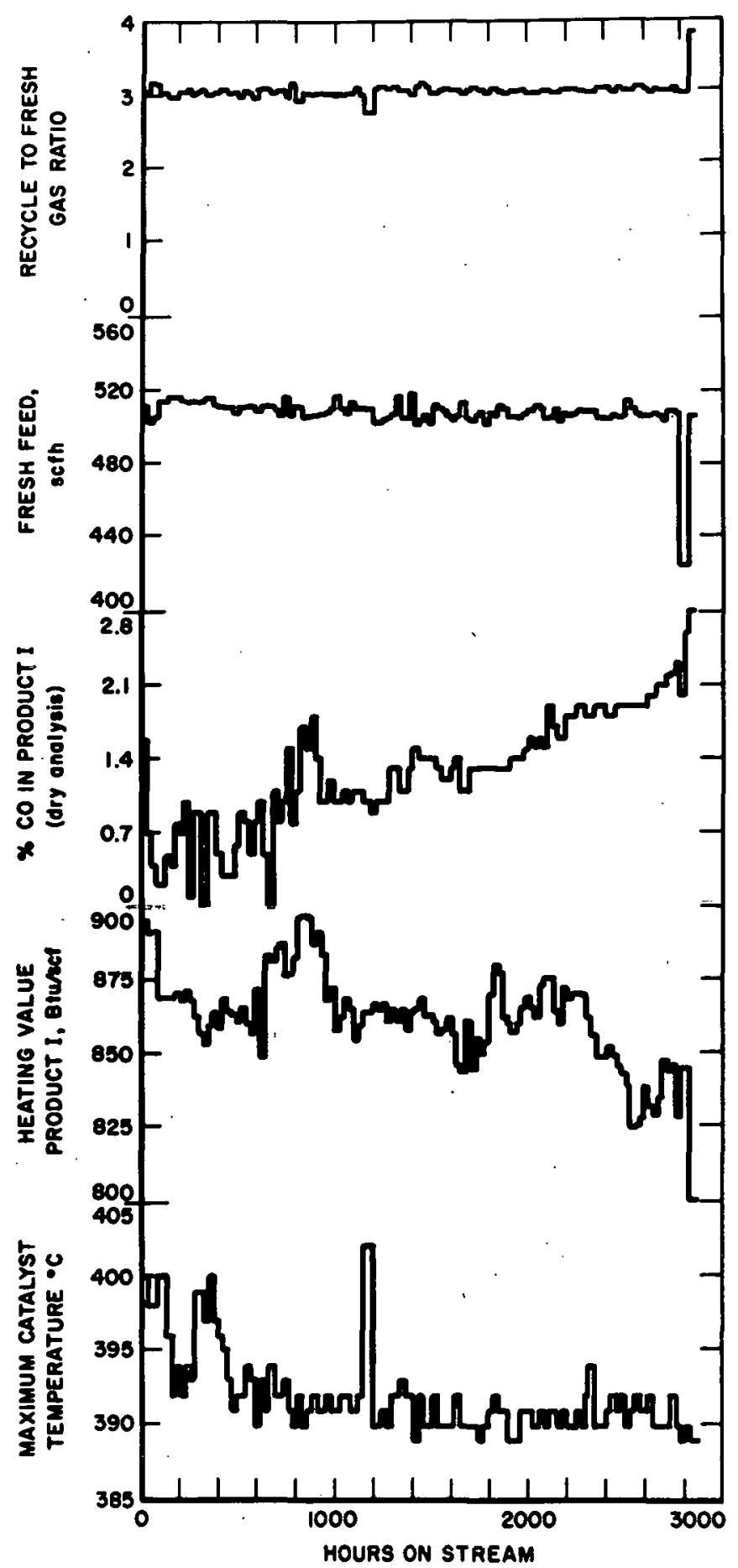

Figure 6: Reactor Conditions and Product Gas Characteristics for TWR-Run 6 


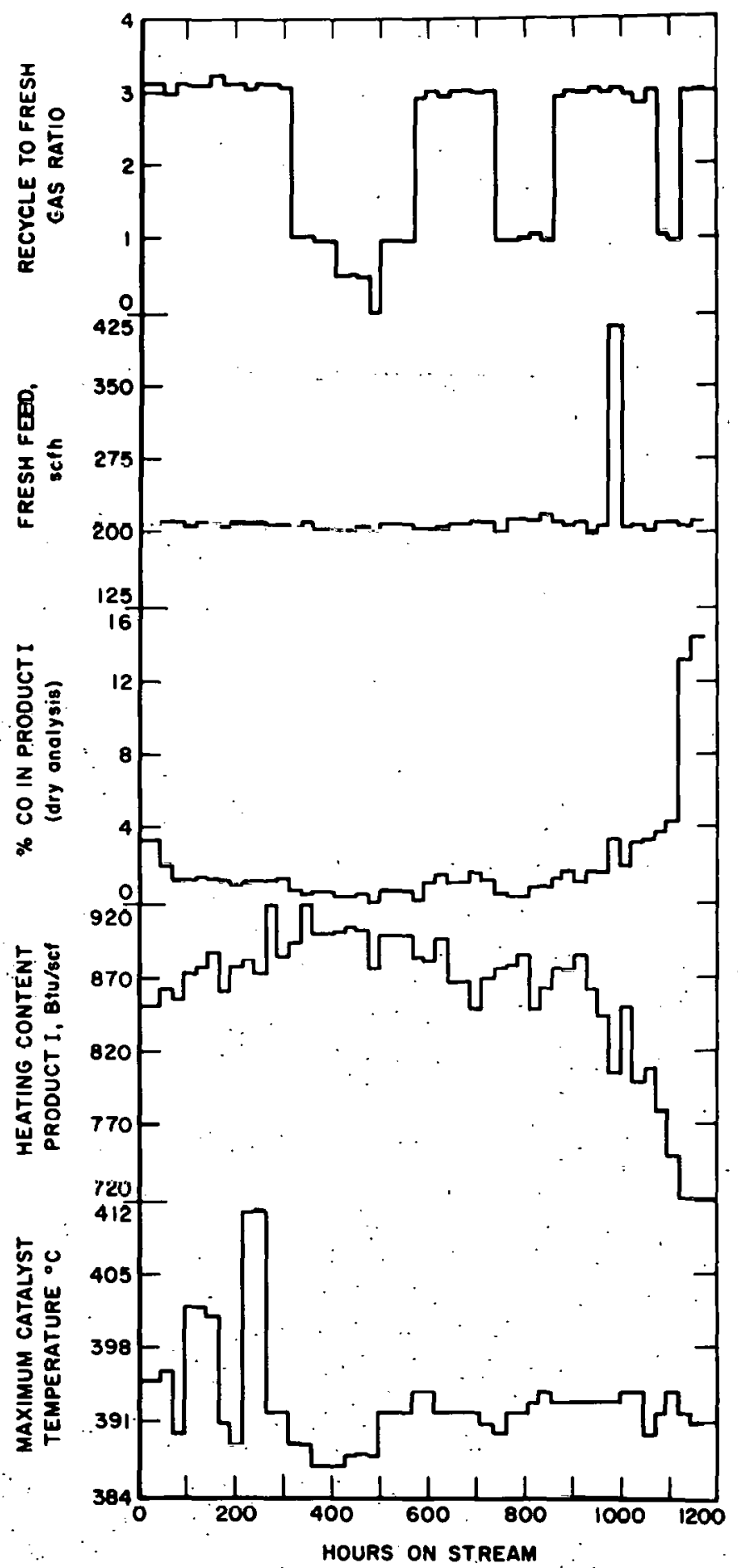

Figure 7: Reactor Conditions and Product Gas Characteristics for TWR-Run 7 


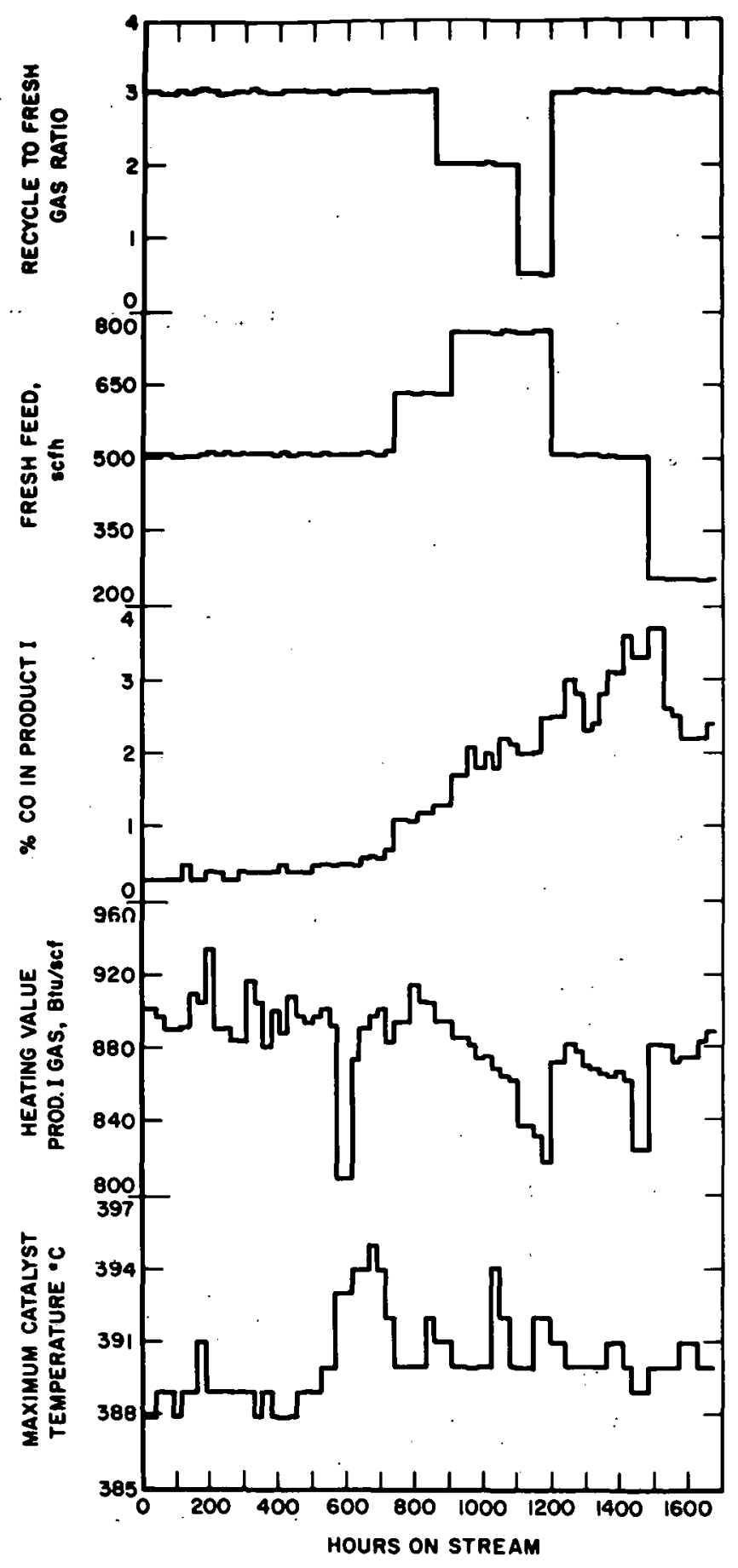

Figure 8: Reactor Conditions and Product Gas Characteristics for TWR-Run 8

10-2-79 L-16998 


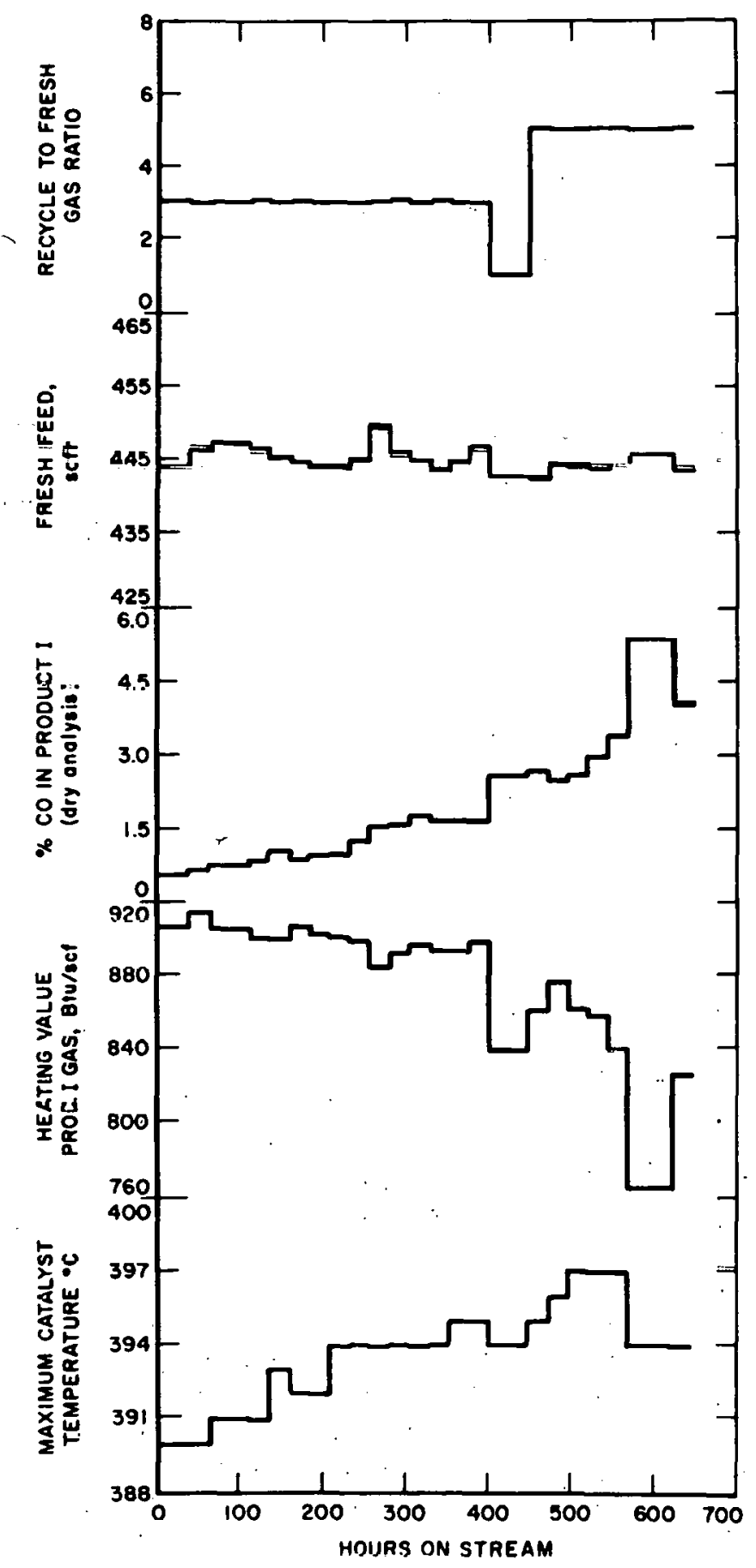

Figure 9: Reactor Conditions and Product Gas Characteristics for TWR-Run 9 


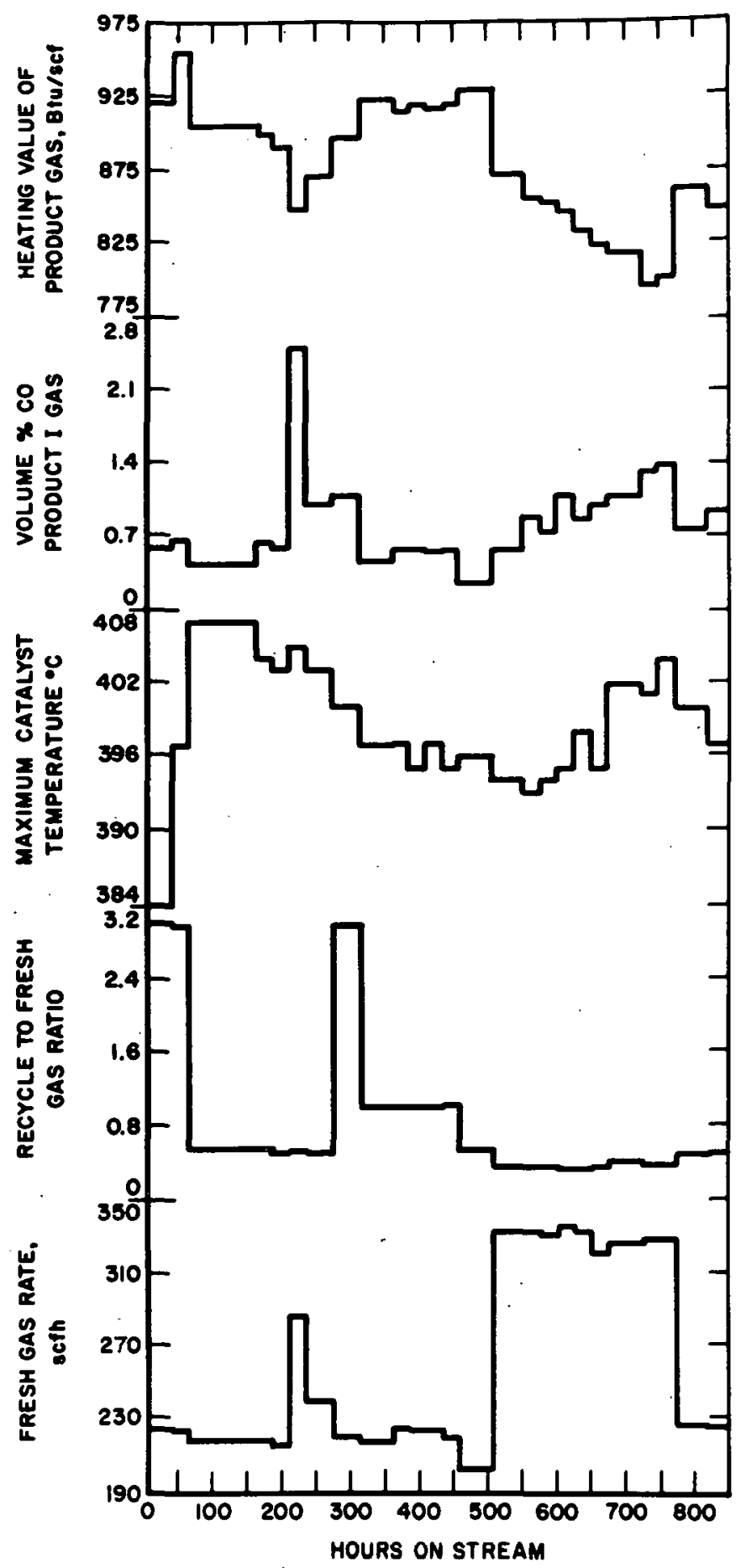

Figure 10: Reactor Conditions and Product Gas Characteristics for TWR-Run 11 
Table 1. - Reactor Characteristics and Activation Parameters

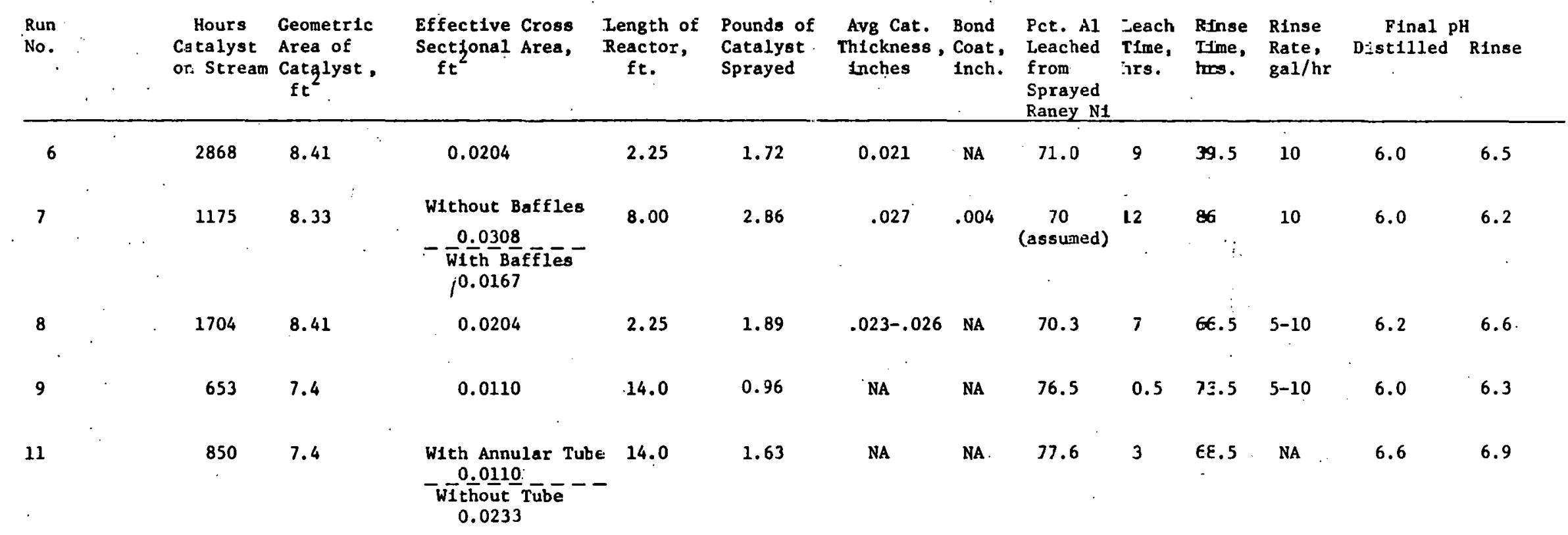

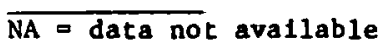


Table 2. - Analyses of Catalyst Samples

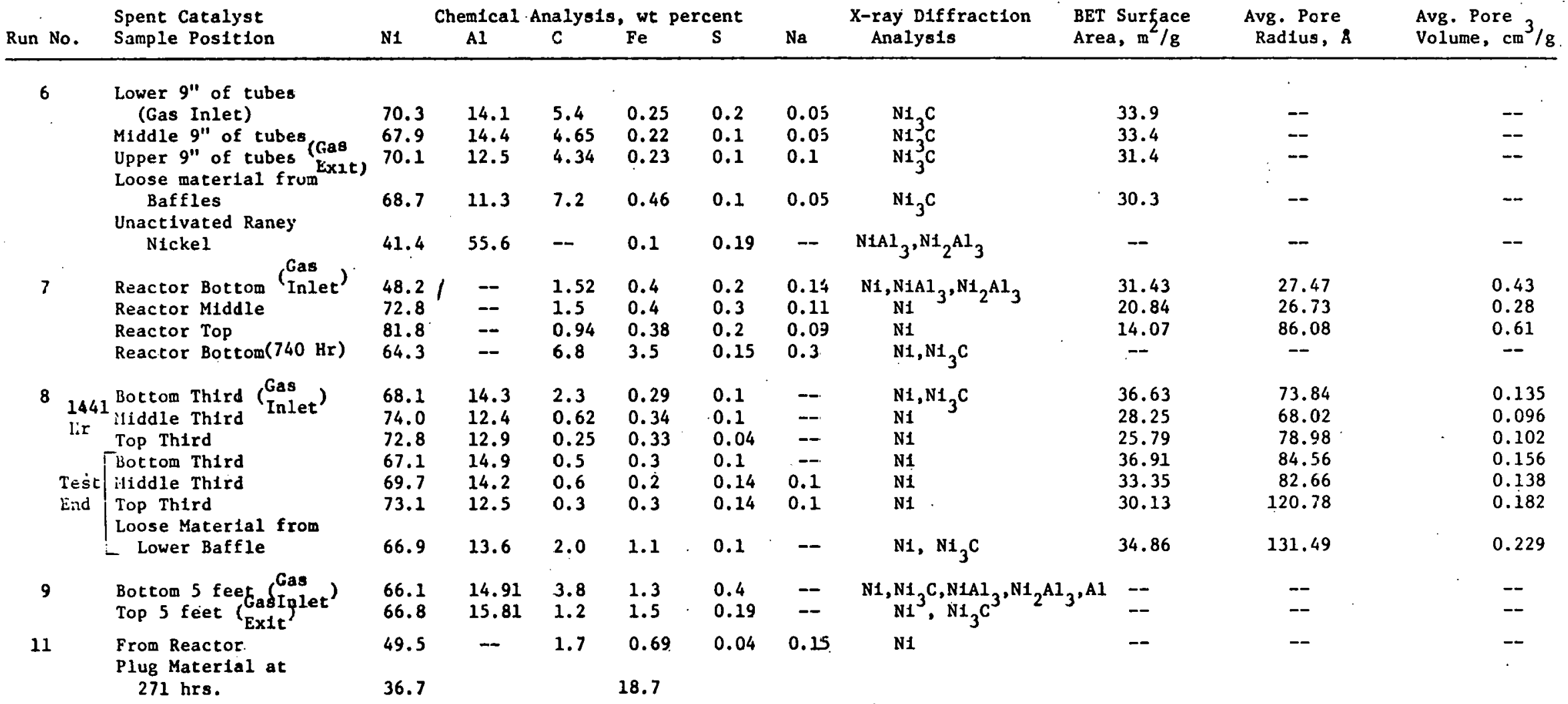


Compositions, vol pct:

Wet Mixed Feed Gas.

$$
\begin{aligned}
& \mathrm{H}_{2} \\
& \mathrm{CO} \\
& \mathrm{CO}_{2} \\
& \mathrm{~N}_{2} \\
& \mathrm{CH}_{4} \\
& \mathrm{H}_{2} \mathrm{O}
\end{aligned}
$$

Dry Product Gas

$$
\begin{aligned}
& \mathrm{H}_{2} \\
& \mathrm{CO} \\
& \mathrm{CO}_{2} \\
& \mathrm{~N}_{2} \\
& \mathrm{CH}_{4}
\end{aligned}
$$

Wet Alralysis, $\mathrm{Il}_{2} \mathrm{O}$

Fresh Feed Rate, scFh

Non-Recycled Product Rate, scFh

Recycle Ratio

Fresh Gas Exposure Velocity, scFh/Ft ${ }^{2}$ catalyst

Mixed Gas Exposure Velocity, scFh/Ft ${ }^{2}$

Fresh Gas $\mathrm{H}_{2} /$ CO Ratio

Mixed Fresh Gas $\mathrm{H}_{2} / \mathrm{CO}$ Ratio

Usage Ratio

Conversion $\mathrm{H}_{2}$, pct

Conversion CO, pet

Heating Value of Dpy Product Gas, $\mathrm{Btu} / \mathrm{scF}$ at $60^{\circ}$ \& latm

System Pressure, psig

Temperature of Inlet Gas, ${ }^{\circ} \mathrm{C}$

Average Catalyst Temperature, ${ }^{\circ} \mathrm{C}$

Maximum Catalyst 'lemperature, ${ }^{\circ} \mathrm{C}$

$\mathrm{H}_{2}$ Recovery

C Recovery

$\mathrm{O}_{2}$ Recovery

Table 3. Selected Test Data TWR-Run 6
30.9

31.4

6.2

7.1

0.2

0.4

1.0

0.8

61.6

60.2

0.1

0.1

16.1

16.9

0.5

1.6

0.3

0.5

1.2

0.9

81.9

80.1

0.3

G.J

511.4

507

134.1

136

3.05

3.08

60.6

59.9

91.5

93.5

3.24

3.21

5.01

4.45

3.08

3.08

57.4

56.3

93.4

81.4

884

872

300

300

381

388

386

388

391

391

90.5

91.2

92.0

92.9

94.5

94.2 
Period Number

Hours on Stream
9

241
14

361
29

809
33

904

Compositions vol pct:

Wet Mixed Feed Gas

$\mathrm{H}_{2}$

$\mathrm{CO}$

$\mathrm{CO}_{2}$

$\mathrm{N}_{2}$

$\mathrm{CH}_{4}$

$\mathrm{H}_{2} \mathrm{O}$

Dry Product Gas

$\mathrm{H}_{2}$

$\mathrm{CO}$

$\mathrm{CO}_{2}$

$\mathrm{N}_{2}$

$\mathrm{CH}_{4}$

Wet Analysis, $\mathrm{H}_{2} \mathrm{O}$

Fresh Feed Rate, scFh

Non-Recycled Product Rate,scFh

Recyele Raliu

30.9

42.6

6.7

12.3

0.2

0.3

0.9

0.8

61.2

43.9

0.1

0.1

16.2

1.2

0.2

0.9

81.5

6.3

211

58.1

3.05

Fresh Gas Exposure Velocity, scFh./Ft catalyst

Mixed Gą Exposure Velocity, scFh $/ \mathrm{Ft}^{2}$ catalyst

Fresh Gas $\mathrm{H}_{2} / \mathrm{CO}$ Ratio

Mixed Feed Gas $\mathrm{H}_{2} / \mathrm{CO}$ Ratio

Usage Ratio

Conversion $\mathrm{H}_{2}$, pct

$\circ$

Conversion $\mathrm{CO}$, pct

Heating Value of Dry Product Gas, $\mathrm{Btu} / \mathrm{scFh}$ at $60^{\circ} \mathrm{F} \&$ latm

System Pressure, psig

Temperature of Inlet Gas, ${ }^{\circ} \mathrm{C} \quad 398$

Average Catalyst lemperature, ${ }^{\circ} \mathrm{C} 403$

Maximum Catalyst Temperature, ${ }^{\circ} \mathrm{C} 411$

$\mathrm{H}_{2}$ Recovery

$\mathrm{C}^{2}$ Recovery

$\mathrm{O}_{2}$ Recovery

93.9

96.3

93.7
10.9

0.6

0.4

1.3

86.8

14.9

212

56.7

$1 . \dot{3} 3$

25.3

28.3

3.08

3.45

2.98

83.7

96.9

918

300

385

386

389

95.4

95.2

91.9
45.0

30.5

12.2

0.3

1.1

41.3

0.1

14.9

0.4

0.4

1.8

82.5

15.6

215

56.0

1.00

25.7

29.6

3.12

3.68

2.97

79.1

97.9

885

300

370

381

392

92.4

88.5

96.8
7.4

0.5

0.9

60.6

0.1

15.5

1.8

0.6

1.2

80.9

6.8

210

52.5

3.02

25.2

38.4

3.11

4.12

3.01

80.2

876

300

370

381

393

89.2

85.0

98.2
58.6

Table 4. Selected Test Data TWR-Run 7 


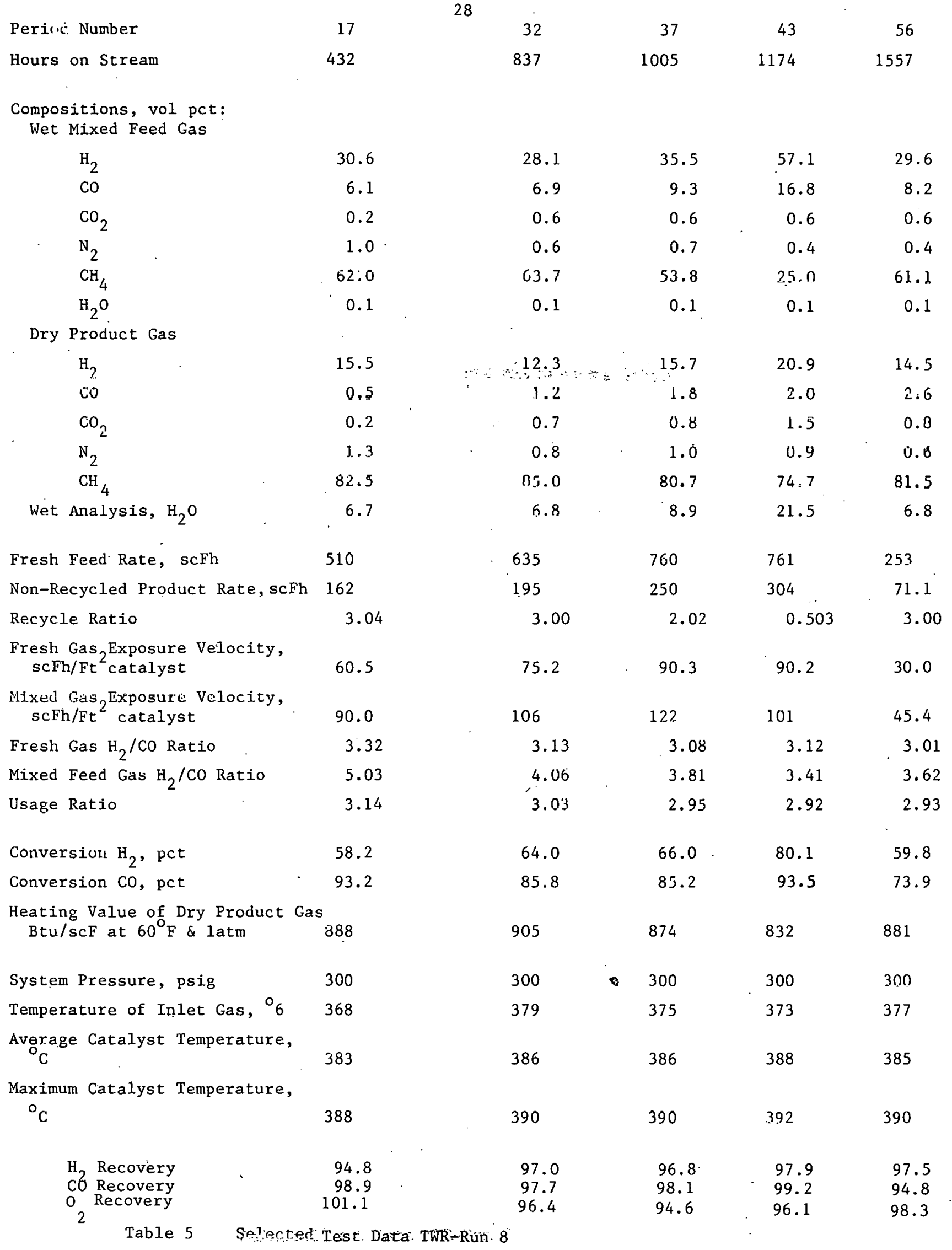


Compositions, vol pct:

Wet Mixed Feed Gas

$\begin{array}{lc}\mathrm{H}_{2} & 27.7 \\ \mathrm{CO} & 6.9 \\ \mathrm{CO}_{2} & 0.8 \\ \mathrm{~N}_{2} & 1.0 \\ \mathrm{CH}_{4} & 63.5 \\ \mathrm{H}_{2} \mathrm{O} & 0.1\end{array}$

46.3

25.8

6.9

13.4

6.6

0.8

1.0

1.3

1.0

0.6

0.8

63.5

38.6

65.4

0.1

0.1

0.1

Dry Product Gas

$$
\begin{aligned}
& \mathrm{H}_{2} \\
& \mathrm{CO} \\
& \mathrm{CO}_{2} \\
& \mathrm{~N}_{2}
\end{aligned}
$$$$
\mathrm{CH}_{4}
$$

Wet Analysis, $\mathrm{H}_{2} \mathrm{O}$

Fresh Feed Rate, scFh

Non-Recycled Product Rate, scFh

Reryc.1e :Ratio

Fresh Gas 2 Exposure Velocity, $\mathrm{scFb} / \mathrm{Ft}$ catalyst

Mixed Gas ${ }_{2}$ Exposure Velocity, $\mathrm{scFh} / \mathrm{Ft}^{2}$

Fresh Gas $\mathrm{H}_{2} / \mathrm{CO}$ Ratio

Mixed Feed Gas $\mathrm{H}_{2} / \mathrm{CO}$ Ratio

Usage Ratio

Conversion $\mathrm{H}_{2}$, pct

Conversion $\mathrm{CO}$, pct

Heating Value of Dry Product Gas, $\mathrm{Btu} / \mathrm{SCF}$ at $60^{\circ} \mathrm{F} \& 1 \mathrm{~atm}$

Systems Pressure, psig

Temperature of Inlet Gas, ${ }^{\circ} \mathrm{C}$

Maximum Catalyst Temperature, ${ }^{\circ} \mathrm{C}$
11.9

1.0

1.0

1.3

. 84.8

7.0

444

135

3.00

59.9

83.1

3.04

4.00

2.86

62.4

87.4

901

300

385

392
100.2

99.3

101

$\mathrm{O}_{2}$ Recovery

Table 6

$\mathrm{H}_{2}$ Recovery

$C$ Recovery

Selected Test Data TWR-Run 9
18.3

15.9

2.6

1.9

1.2

76.1

14.6

443

161

1.03

3.0

1.5

1.0

78.6

4.3

444

141

5.00

59.7

59.9

72.5

117

3.07

3.03

3.46

3.88

2.85

2.88

70.5

43.3

85.4

58.4

838

858

300

300

384

382

394

397

98.5

98.7

100.6

98.9

98.2

99.8 
Period Number

Hours on Stream
2

67

Compositions, vol pct:

Wet Mixed Feed Gas

$\begin{array}{lrrrr}\mathrm{H}_{2} & 23.3 & 53.2 & 42.7 & 61.6 \\ \mathrm{CO} & 6.7 & 16.0 & 12.6 & 18.7 \\ \mathrm{CO}_{2} & 0.6 & 0.7 & 0.6 & 0.7 \\ \mathrm{~N}_{2} & 0.7 & 0.5 & 0.7 & 0.3 \\ \mathrm{CH}_{4} & 68.6 & 29.5 & 43.3 & 18.7 \\ \mathrm{H}_{2} \mathrm{O} & 0.1 & 0.1 & 0.1 & 0\end{array}$

Dry Product Gas

$\mathrm{H}$,
$\mathrm{CO}$

5.6

11.8

9.9

19.8

0.7

0.6

0.6

0.9

$\mathrm{CO}_{2}$

0.8

1.8

1.1

2. 5 .

$\mathrm{N}_{2}$

1.0

1.4

1.1

1. 3

$\mathrm{CII}_{4}$

84.6

87.0

75.5

Wet Analysis, $\mathrm{H}_{2} \mathrm{O}$

7.0

21.9

14.8

25.1

Fresh Feed Rate, scFh

225

219

225

332

Non-Recycled Product Rate,siFh 66.5

81.8

76.6

140

Recycle Ratio

2.95

0.536

0.992

0.327

Fresh Gas ${ }_{2}$ Exposure Veloc1ty, saFh/Ft ${ }^{2}$ catalyst

30.3

29.5

30.3

44.9

Mixed Gas ${ }_{2}$ Exposure Velocity, orfh! $5 t^{2}$

35.9

31.5

33.4

47.9

Fresh Gas $\mathrm{H}_{2} / \mathrm{CO}$ Ratio

3.09

3.12

3.07

3.06

i'ixed Feed Gas $\mathrm{H}_{2} / \mathrm{GO}$ Ratio

3.49

3.33

3.40

3.29

Usabe Ratio

3.05

3.01

2.98

2.84

Conversion $\mathrm{H}_{2}$, pct

80.4

88.3

85.1

84.4

Conversion $\mathrm{CO}$, pct

91.9

97.8

97.2

97.7

Heating Value of Dry Product Gas Btu/SCF at $60^{\circ} \mathrm{F} \& 1$ atm

954

899

917

835

Systcm Pressure, psig 300

300

300

300

Temperature of Inlet Gas, ${ }^{\circ} \mathrm{C} \quad 377$

382

385

380

$\underset{{ }^{\circ} \mathrm{C}}{\operatorname{Maximum} \text { Catalyst Temperature, }}$

$\mathrm{H}_{2}$ Recovery

$\mathrm{C}^{2}$ Recovery

$\mathrm{O}_{2}$ Recovery 